\title{
Sosyal Sermaye İle İşsizlik Kaygısı Arasındaki İlişki: Atatürk Üniversitesi ïiBF Son Sınıf Öğrencileri Üzerine Bir Uygulama*
}

\section{Relationship Between Social Capital and Unemployment Anxiety: An Application on Last Class Students at Ataturk University Faculty of Economics and Administrative Sciences}

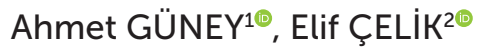

\section{öz}

Çoğu ülkelerde olduğu gibi Türkiye'de de çözüme kavuşturulmayı bekleyen en önemli sosyo-ekonomik sorunların başında işsizlik yer almaktadır. İşsizliğin bireyler üzerinde birtakım ekonomik, psikolojik ve sosyal etkiler yarattığı bilinmektedir. İşsizliğin bireyler üzerinde yarattığı en önemli etkilerden biri de işsizlik kaygısıdır. 15-24 yaş aralığında yer alan bireylerin gelecekleriyle ilgili ümitsizliğe kapılmalarında ve işsizlik kaygısı yaşamalarında işsizlik önemli bir paya sahiptir. STK'ya üyeliğin, çevreden sağlanan sosyal desteklerin ve sosyal sermayenin bireyler üzerindeki işsizlik kaygısını azaltacağı düşünülmektedir. Bu düşünce doğrultusunda yapılan bu araştırmada; üniversite son sınıf öğrencilerinin sosyal sermayeleriyle işsizlik kaygıları arasında anlamlı bir ilişkinin olup olmadığı analiz edilmiştir. Atatürk Üniversitesi İktisadi ve İdari Bilimler Fakültesi son sınıf öğrencileri üzerinde uygulanmış olan bu çalışmada, bu iki değişken arasındaki ilişkinin varlığı korelasyon analizi ile ortaya konulmuştur. Çalışmaya katılan ve uygun bulunan 155 katılımcıdan alınan cevaplar üzerinden analiz gerçekleştirilmiştir. Çalışmanın sonucunda sosyal sermaye ile işsizlik kaygısı arasında negatif yönlü bir ilişki olduğu ve sosyal sermaye düzeyleri yüksek olan bireylerin işsizlik kaygılarının azalacağı tespit edilmiştir. Cinsiyete göre; kadınlarda işsizlik kaygısı erkeklerde ise sosyal sermaye düzeyi daha yüksek çıkmıştır. Sosyal sermaye düzeyleri yükseldiğinde öğrencilerin işsizlik kaygılarının azalacağı ve bu yönde geleceğe daha ümitli bakacakları sonucuna varılmıştır.

Anahtar kelimeler: Sosyal sermaye, İşsizlik, İşsizlik kaygısı JEL Sınıflaması: B55, D39, E24

DOI: 10.26650/ISTJECON2019-0005

\begin{abstract}
*Bu çalışma; 6-7 Aralık 2018 tarihinde BalıkesirBandırma'da düzenlenen "II. International Symposium on Economics, Finance and Econometrics (ISEFE 2018)" isimli programda sunulan tebliğ özetinin gözden geçirilmiş ve genişletilmiş halidir.

'Assist. Prof., Atatürk University, Faculty of Economics and Administrative Sciences, Department of Division of Labour Economics and Industrial Relations, Erzurum, Turkey

${ }^{2}$ Phd Student, Atatürk University, Institute of Social

Sciences, Labour Economics and Industrial Relations, Erzurum, Turkey
\end{abstract}

ORCID: A.G. 0000-0002-9411-0483;

E.Ç. 0000-0003-3194-9123

Corresponding author/Sorumlu yazar: Ahmet GÜNEY,

Atatürk University, Atatürk University, Faculty of Economics and Administrative Sciences, Department of Division of Labour Economics and Industrial Relations, Yakutiye, Erzurum, Turkey

E-mail/E-posta: guney@atauni.edu.tr

Submitted/Başvuru: 13.03.2019

Revision Requested/Revizyon Talebi: 21.05.2019 Last Revision Received/Son Revizyon:

14.06.2019

Accepted/Kabul: 17.06.2019

Citation/Atıf: Guney, A., Celik, E. (2019). Sosyal sermaye ile işsizlik kaygısı arasındaki ilişki: Atatürk Üniversitesi İïBF son sınıf öğrencileri üzerine bir uygulama. Istanbul iktisat Dergisi - Istanbul Journal of Economics, 69(1), 103-131.

https://doi.org/10.26650/ISTJECON2019-0005 


\section{ABSTRACT}

Unemployment is one of the most important socio-economic problems waiting to be solved in Turkey as in most countries. It is known that unemployment creates economic, psychological and social effects on individuals. One of the most important impacts of unemployment on individuals is unemployment anxiety. Unemployment has a significant place in desperation of future and anxiety of unemployment of individuals aged 15-24. It is thought that membership of an NonGovernmental Organizations, social support from the environmental and social capital will reduce the unemployment anxiety on individuals. In this study, it has been analyzed whether there is a significant relationship between the social capitals and unemployment concerns of university senior students or not. In the study which was applied on the senior students of Atatürk University Faculty of Economics and Administrative Sciences, the existence of the relationship between these two variables was revealed by correlation analysis. The analysis was performed on the responses received from 155 participants who were found to be eligible for the study. As a result of the study, it is showed that there is a negative relationship between social capital and unemployment anxiety, furthermore individuals with high social capital levels decrease their unemployment anxiety. In terms of gender; the level unemployment concerns were higher among women, while in males, the level of social capital was higher. It was concluded that increasing social capital levels of individuals would reduce unemployment concerns and would look more hopeful to the future in this direction.

Keywords: Social capital, Unemployment, Unemployment anxiety

JEL Classification: B55, D39, E24

\section{EXTENDED ABSTRACT}

In the historical process, the concept of social capital has been the subject of a variety of research in fields such as economics, sociology, business administration and political sciences. Social capital, which has become increasingly important in social structure and it has been used frequently in literature, trust, social networks and norms which consist a structure that support each other. The social capital required inside of social structure varies according to the level of development levels of the countries. The existence of these differences paves the way for the weakening of social networks and decreasing trust in society.

Another factor that is important for humanity and which takes its place in literature in this direction is anxiety. Anxiety is defined as the tension and fear that individuals feel instinctively against a threat. There are many economic, social and psychological reasons that cause individuals to be anxious during their lives, and they have an impact on despair. The main reason for this is the unemployment phenomenon related to the future of individuals. The overall unemployment rate for our country is $10,8 \%$ and the youth unemployment rate is $22 \%$. This 
situation, shows that the most effected group by unemployment are the young individuals in the rage 15-24.

The aim of this study is to determine whether there is a meaningful relationship between the social capital of the senior students and the unemployment concerns or not. In this context, the research sample includes senior students in the Faculty of Economics and Administrative Sciences of Erzurum Atatürk University. In this study it is preferred data collection method based on quantitative data. The existence of the relationship between these two variables is tried to be revealed by correlation analysis. SPSS 22 statistical program was used to analyze the data. As a result of the study, a negative relationship was found between social capital and unemployment anxiety As the social capital of individuals increased, unemployment concerns decreased. In this respect, it can be interpreted that as the social capital of the students increases, the unemployment concerns related to their future will decrease in the opposite direction. According to the hypothesis results, there is a higher relation between social capital and unemployment anxiety sub-dimensions, personal pessimism and lack of self-confidence compared to other sub-dimensions. It can be said that a significant relationship was found between social capital and the lower dimensions of unemployment anxiety. As a matter of fact, as the social capital of students increases, there will be a decrease in personal pessimism and lack of self-confidence, and there will be decreases in social pressures and effects of their environment

When the relationship between the sub-dimensions of social capital and unemployment anxiety is examined; It has been noted that the relationship between the value of life, which is one of the sub-dimensions of social capital, and unemployment anxiety has a higher rate than other sub-dimensions. As a result, any increase in the sub-dimensions of social capital reduces the unemployment concerns of individuals and it enables individuals to be hopefull about the their future.

As a result of the differences analysis performed, social capital and unemployment anxiety levels differed according to the demographic 
characteristics of the students. It was observed that women's perception of unemployment anxiety was higher than that of men. It can be said that the fact that women cannot find a working area in every sector in the labor market is effective in having unemployment anxiety about their future. As a result of the analyzes, it has been observed that the unemployment anxiety of the students who have work experience have a lower rate compared to the students who cannot have work experience. It was revealed that men's perceptions of social capital were higher than women. It was observed that the individuals who had relatives in the job-finding point had higher rates of social capital perceptions than those who had no relatives in terms of employment. Unemployment concerns of the young people with high social capital have been low and an opposite relationship has been found between these two variables. 


\section{Giriş}

İktisat, sosyoloji, işletme ve siyasal bilimler açısından da incelemelere konu olan sosyal sermaye; 1916 yılında Hanifan'ın ilk kez bu kavramı kullanmasıyla birlikte literatürdeki yerini almaya başlamıştır. Toplum açısından önem ihtiva eden bu olgu toplum içerisinde bireylerin koordinasyon içerisindeki faaliyetlerinin kolaylaşmasını sağlayan ve bu doğrultuda etkinliğin artmasında rol oynayan güven, norm ve sosyal ağların birlikte sacayak oluşturduğu bir yapı olarak bilinmektedir.

İnsanlık açısından önem arz eden ve bu doğrultuda sıklıkla literatürdeki yerini alan bir diğer olgu da kaygıdır. Bireyler üzerinde önemli bir etkiye sahip olan bu kavram bireylerin tehdit karşısında hissettikleri gerginlik ve korku olarak tanımlanmaktadır. Bireylerin yaşamları boyunca kaygılarını tetikleyen ve harekete geçiren birçok ekonomik, sosyal ve psikolojik unsur bulunmaktadır. Bu unsurların başında da bireylerin gelecekleriyle ilintili olan işsizlik olgusu gelmektedir. Toplumların post-modern yapıya geçişleriyle birlikte sermayenin yoğun olduğu iş gücü piyasaları ortaya çıkmıştır. Bu dönemde önemini yitiren mavi yakalı çalışanların yerini beyaz yakalı bireyler almaya başlamıştır. Yine bu yönde teknolojik gelişmelerin artış göstermesiyle insan gücünün yaptığı işi daha kısa sürede yapan makinelerin icadıyla işsizlik olgusu oldukça önem arz eden bir durum olmaya başlamıştır.

Ülkemiz açısından genel işsizlik oranlarının \%10,8 genç işsizliğin \%22 civarında seyretmesi ve bu doğrultuda piyasadaki mevcut işlerle bireylerin nitelik ve becerilerinin uyuşmuyor olması, bireylerin mezuniyete yakın dönemlerde işsizlik kaygısıyla karşı karşıya kalmalarına yol açacaktır. Günümüzde sayısı artmakta olan üniversiteler, gelecek nesillerin yetiştirilmesi ve bu yönde belirli beceriler ve nitelikler kazanmalarında önemli bir yapıya sahiptir. $\mathrm{Ne}$ yazık ki günümüz şartlarında bu kadar eğitim düzeyi yüksek üniversite mezunu birey olmasına rağmen işsizlik olgusuna en fazla yine bu bireyler maruz kalmaktadır. Aynı koşullarda benzer nitelik ve becerilere sahip bireylerin çokluğu piyasa koşullarında rekabeti tetiklemektedir. Bu durum da bireylerin iş 
bulma konusundaki beklentilerinin, kaygılarının ve umutsuzluklarının artmasına yol açmaktadır.

Sosyal sermayenin, başkaları tarafından sağlanan sosyal desteklerin, zorlu süreçlerde sosyal çevreden sağlanan maddi ve manevi yardımların mezun konumunda olan bu bireyler üzerinde bir takım etkiler yarattığı bilinmektedir. Bu etkilerden en önemlisi işsizlik kaygısının azaltılması yönündedir. Geleceğe yönelik ümitsizlik içerisinde olan bireylerin belli bir sosyal gruba, sosyal ağa, çevreye bağlılıkları bu bireyler üzerinde işsizlik kaygısını azaltıcı bir etkiye sahiptir. Sosyal sermayesi yüksek olan bireyler geleceğe yönelik daha olumlu bakmakta ve işsizlik kaygısından daha az etkilenmektedir. Bu çalışmada, bireylerin sosyal sermayeleri ile işsizlik kaygıları arasında anlamlı bir ilişkinin olup olmadığını tespit etmek amacıyla Erzurum Atatürk Üniversitesi İktisadi ve İdari Bilimler Fakültesi son sınıf öğrencilerinin dahil edildiği bir alan araştırması yapılmıştır. Çalışmanın ilk kısmında sosyal sermayenin kavramsal çerçevesine yer verilmiş ve çalışmanın devamında ise önem arz eden diğer bir konu olan işsizlik kaygısı ele alınmıştır.

Çalışmanın üçüncü kısmında ise, sosyal sermaye ve işsizlik kaygısı arasındaki ilişki incelenmiştir. Bu yönde çalışmanın metodolojisi oluşturulmuş ve burada yer alan hipotezlerin doğruluğunun tespiti ve anlamlılığını ortaya koymak açısından verilerin analizine yer verilmiştir. Son olarak sonuç kısmında ise, konuyla ilgili genel bir görüş ifade edilmiştir.

\section{Sosyal Sermayenin Kavramsal Çerçevesi}

Kelime olarak bireyin tüm varlığını ihtiva eden servetin bir karşılı̆̆ı olarak bilinen sermaye kavramı Türk Dil Kurumu tarafından "ticaret işinin kurulması, yürütülmesi için gereken anapara ve paraya çevrilebilir malların tamamı, anamal, başmal, kapital, meta, resülmal" olarak tanımlanmaktadır (Türk Dil Kurumu [TDK] Online Sözlükleri). Belirli bir ihtiyacın giderilmesi amacıyla kullanımı gerçekleştirilecek birikim, varlık ve kaynaklar için kullanılmaktadır. Sermayeyi maddi ve gayri maddi varlıklar olarak ifade eden işletmeler aynı zamanda diğer 
malları imal edebilmek için kullanmış oldukları makine, araç, teçhizat ve fabrikalarında bir sermaye unsuru olduğunu ifade etmektedirler (Yıldırım ve ark., 2013). Küreselleşme, bilgi ve iletişimin etkisiyle içeriği genişletilmiş olan sermaye iktisatçılar tarafından; üretim faktörlerinden biri olarak görülmekte ve bireyler tarafından üretilmiş üretim araçları olarak nitelendirilmektedir (Tatlı, 2013).

Sosyal sermaye olgusu, sosyal bilimlere ait "sosyal" kavramı ile iktisat bilimine ait "kapital-sermaye" kavramlarının bir araya gelmesiyle oluşturulmuş bir terimi ifade etmektedir (Büyükilikmen, 2015). Sosyal sermayenin tarihsel sürecine bakıldığında; sosyal sermaye olgusunun her ne kadar kalkınma teorisinde kullanılmış olduğu görülse de asıl çıkış noktasının sosyolojik araştırmalar olduğu göze çarpmaktadır. Bu doğrultuda 20. yy başlarında Max Weber "Protestan Ahlakı ve Kapitalizm Ruhu" adlı çalışmasında sosyal sermayeye değinmiş olduğu görülmektedir (Tüysüz, 2011). Her ne kadar Max Weber sosyal sermaye kavramına değinmiş olsa da sosyal sermaye teriminin ilk kullanımı L. J. Hanifan'ın 1916 yılında gerçekleştirdiği Kırsal Okul Topluluk Merkezi (The Rural School Community Center) adlı çalışmasıyla ortaya çıkmıştır (Putnam, 2000). Nitekim uzun bir entelektüel geçmişe sahip olduğu görülen sosyal sermaye kavramının literatürde tam bir tanımı olmamakla birlikte birçok araştırmacı tarafından farklı şekillerde tanımlanmış olduğu göze çarpmaktadır. Bu tanımlara bakıldığında; "içsel büyüme teorilerinde ekonomik gelişmeye ve büyümeye doğrudan veya dolaylı olarak katkıda bulunan, her türlü maddi ve maddi olmayan; politik, örgütsel, çevresel, entelektüel, kültürel, beşeri, bilimsel, teknolojik ve sosyal unsurlar sermaye olarak kabul edilmektedir" (Karagül ve Masca, 2005). ìktisadi anlamda sosyal sermaye, kişi ve kuruluşlar arasında güvene bağlı olarak gerçekleştirilen ilişkilerin iktisadi faaliyet ve oluşumlara yansıması olarak tanımlanmaktadır (Karagül, 2015).

Sermayenin üç boyutunu her bir sınıf kavramıla ele alan ve ilişkilendiren Bourdieu, sosyal sermayenin sınıf çatışmalarına vurgu yaptığını dile getirmiştir. Toplumsal mücadelelerde bir kaynak haline gelen sosyal sermaye olgusu; sosyal ilişkilerde bir bireyin çıkarlarını geliştirebilme ve yeteneğini artırabilme olarak tanımlanmaktadır (Sabatini, 2006). Bourdieu (1986) tarafından sosyal sermaye olgusu; "karşılıklı tanıdıklık ve tanınmanın az ya da çok kurumsallaşmış ilişkilerden 
oluşan dayanıklı bir ağa veya bir gruba üyeliğe bağlı gerçek ya da potansiyel kaynakların toplamı" şeklinde de ifade edilmektedir. Woolcock \& Narayan (1999), 1990'lı yıllarda sosyal sermaye olgusunu bireylerin toplu halde hareket etmelerini sağlayan norm ve ağlar olarak ifade etmektedirler. Putnam ise sosyal sermayeyi, bireylerin koordinasyonlu faaliyetlerini kolaylaştırarak toplumun etkinliğinin artmasında rol oynayan güven, norm ve sosyal ağlar gibi sosyal organizasyon özellikleriyle ifade edilebilen bir kavram olarak tanımlanmaktadır (Putnam, 1993). Putnam aynı zamanda, sosyal sermayeyi bölgesel seviyede ele alarak sosyal sermaye olgusunun demokratik kurumlar üzerinde ve ekonomik kalkınma üzerinde nasıl destekleyici bir etkiye sahip olduğunu ele almaktadır (Özpınar ve ark., 2016). Sosyal sermeye Fukuyama (2001) tarafından yapılan çalışmada ise, iki veya daha fazla birey arasında işbirliğini teşvik eden bir olgu olduğu dile getirilmiştir.

\section{3. İşsizlik Kaygısı}

İnsanlık tarihi açısından önem arz eden ve bu doğrultuda sıklıkla literatürlerde yerini alan kaygı kavramı geçmişten günümüze devam eden bir olgu olarak çeşitli şekillerde incelenmiş ve birçok araştırmacı tarafından farklı şekillerde tanımlamalara konu olmuş bir kavramdır. Kaygı kavramının tarihsel süreci incelendiğinde bu kavramın kullanımının 1500'lü yıllar itibariyle gerçekleşmiş olduğu görülmektedir. İngilizce "anxiety" kavramından çevrilerek dilimize 'anksiyete' olarak geçen bu kavram Latinceden türetilmiş olup ajitasyon, endişe ve sıkıntı ile karakterize edilmekte ve bünyesinde korku içeren bir olgu olarak nitelendirilmektedir (Niggemeyer-Hall, 2001). Dilimizde ise endişe, tasa, üzüntü ve duyulan düşünce (TDK Online Sözlükleri) olarak tanımlanan kaygıyı Freud "hissedilen şey" olarak nitelendirmiş ve Miller ise bu doğrultuda kaygıyı, "korkuya benzetilen bir kavram olup bu doğrultuda öngörücü reaksiyonlar" olarak tanımlanmaktadır (Fitzgerald, 1997).

İş kökünden türetilmiş bir olgu olan işsizlik kavramı ise literatürlerde çeşitli şekillerde ifade edilmektedir. Bu doğrultuda, dilimizde "bireyin herhangi bir işinin olmama" durumunu ifade etmekte olan işsizlik kavramı, çalışma istek ve yeteneğine 
sahip olan bireyin piyasa koşullarında daimi gelir sağlayabileceği geçerli ücret haddinde makul bir iş bulamama durumu olarak tanımlanmaktadır (Işığıçok, 2017). İşsizlik olgusundan en fazla etkilenen kesimler incelendiğinde 15-24 yaş gurubunu kapsayan gençlerin daha sıklıkla karşı karşıya kaldıkları sosyo-ekonomik sorunların başında geldiğini görmekteyiz.

Genç işsizlik olgusundan önce genç kavramını açıklamakta fayda vardır. Genç kavramı dilimizde "yaşı ilerlememiş olanlar" ve bu doğrultuda "gelişimini tamamlamamış" olanlar olarak nitelendirilmektedir (TDK Online Sözlükleri). Birleşmiş Milletler 15-24 yaş aralığında yer alan bireyleri genç olarak tanımlamaktadır. Bireylerin yaşamlarının belirli dönemlerini kapsayan ve genç olma durumunu ifade eden gençlik olgusu ülkeden ülkeye bölgeden bölgeye farklılık gösterdiği görülmektedir (United Nations Educational, Scientific and Cultural Organization [UNESCO], 2015). Genç işsizlik, çalışma çağı içerisinde yer alan 15-24 yaş grubundaki bireylerin işsizliğini ifade etmektedir. Genç olarak nitelendirilen 15-24 yaş aralığındaki bireylerin işe alım evrelerinde işverenler tarafından ayrımcılığa maruz bırakılmaları genç işgücünün talep yönünün bir göstergesidir. Piyasa şartlarında cari ücret düzeyinde 15-24 yaş grubundaki genç bireylerin boş zamanı çalışmaya tercih etmeleri ve bu doğrultuda iş etiğine sahip olmamaları da genç işgücünün arz yönünün göstergesi olarak nitelendirilmektedir (Coşan ve ark., 2017).

15-24 yaş grubunda yer alan bireyler genel işsizlikten ve durgunluktan en fazla etkilenen gruplar olarak bilinmektedir. Çünkü bu gruplarda yer alan gençler piyasaya yeni girdikleri ve istihdama yeni katıldıkları için deneyimsiz durumdadırlar. Çalışma geçmişleri ya hiç yoktur ya da çok kısa süreliğine olmuştur. Bu yüzden piyasanın en kıdemsiz üyeleri olduklarından işsizliğin artış gösterdiği dönemlerde bu yönde en fazla etkilenen kesimin de yine gençler olduğu görülmektedir (Işık, 2016). İşsizlik olgusu 15-24 yaş grubunda yer alan gençler üzerinde ekonomik ve toplumsal açıdan maliyetler yüklemektedir. Bilindiği üzere işsizliğin bireyler üzerinde yarattığı ekonomik etkilerin başında genel itibariyle gelir kaybı gelmektedir. Zaman içerisinde bireyler ekonomik açıdan kaybettikleri geliri telafi edebilmekteyken; güvensizlik, korku, umutsuzluk ve sefalet gibi sosyal etkiler bireyler üzerinde telafi edilmesi daha 
güç kalııı etkiler yaratabilmektedir. Bir gencin geleceğiyle ilgili iş beklentilerinde sürekli olarak hayal kırıklığına uğraması hayatı boyunca devam edecek davranış bozukluklarına da sebebiyet verecektir (Erdayı, 2009).

Tablo 1: Eğitim Düzeyine Göre Genç İşsizlik Oranları (15-24 Yaş Grubu), 2010-2014

\begin{tabular}{|c|c|c|c|c|c|c|c|c|c|c|c|c|}
\hline \multirow[b]{2}{*}{ 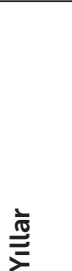 } & \multicolumn{3}{|c|}{ Okuryazar değil } & \multicolumn{3}{|c|}{ Lise Altı Eğitimliler } & \multicolumn{3}{|c|}{$\begin{array}{c}\text { Lise ve Dengi } \\
\text { Meslek }\end{array}$} & \multicolumn{3}{|c|}{ Yüksek Öğretim } \\
\hline & 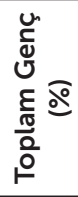 & 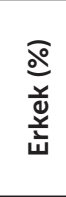 & 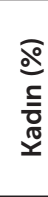 & 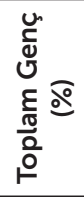 & $\begin{array}{l}\widehat{ᄋ} \\
\text { 일 } \\
\frac{y}{4}\end{array}$ & 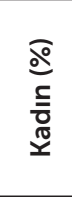 & 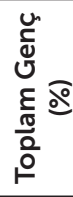 & 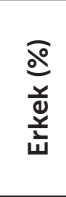 & 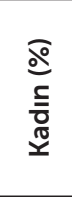 & 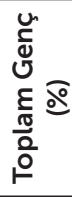 & $\begin{array}{l}\widehat{\bigcirc} \\
\stackrel{y}{d} \\
\text { 妾 }\end{array}$ & 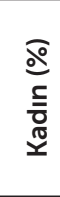 \\
\hline 2010 & 16,4 & 24,4 & 9,5 & 18,1 & 19,5 & 14,7 & 25,4 & 22,4 & 30,2 & 32,5 & 27,5 & 36,5 \\
\hline 2011 & 11,2 & 21,1 & 4,1 & 14,5 & 15,4 & 12,4 & 21,8 & 18,6 & 27,3 & 30,0 & 24,0 & 35,6 \\
\hline 2012 & 9,0 & 16,3 & 2,9 & 14,1 & 15,1 & 11,7 & 19,4 & 16,4 & 24,7 & 28,5 & 23,0 & 33,7 \\
\hline 2013 & 10,3 & 18,3 & 5,9 & 15,5 & 15,9 & 14,4 & 20,2 & 16,9 & 25,7 & 29,2 & 23,4 & 34,2 \\
\hline 2014 & 12,1 & 19,1 & 8,6 & 14,8 & 15,5 & 12,8 & 19,8 & 16,8 & 24,9 & 28,3 & 23,2 & 33,1 \\
\hline
\end{tabular}

Kaynak: Türkiye İstatistik Kurumu (TÜiK), İstatistiklerle Gençlik/Youth Statistic 2014, s. 50.

Yukarıdaki tablo incelendiğinde yıllar itibariyle eğitim seviyesi artıkça genç işsizlik sayısının da artış gösterdiği görülmektedir. İşsizliğin en yoğunlukta olduğu kesim yükseköğrenim alan bireylerin olduğu kesim olarak dikkatleri çekmektedir. Yapı içerisinde yükseköğrenime sahip kadın bireylerin işsizlik oranlarının en yüksek oranlarda yer aldığını ve okur-yazar olmayan kadın bireylerin ise erkeklerden daha az oranlarda işsizlik oranlarına sahip olduğunu görmekteyiz. Okuryazar olmayan ve lise altı eğitim alan 15-24 yaş aralığındaki kadınların işsizlik oranlarının erkeklere göre oldukça düşük bir seyir izlediğini görülmektedir. Lise ve yükseköğrenim eğitim seviyesine sahip bireylerde ise bu durum tersi yönde yüksektir. Burada asıl önemli husus eğitim seviyesi arttıkça işsizlik oranlarının da artış göstermesidir. Cinsiyet açısından incelendiğinde genç kadınların eğitim seviyesi arttıkça erkeklere oranla daha fazla işsizlik olgusuyla karşı karşıya kaldıklarını görmekteyiz. Eğitim seviyesi artan kadın işgücünde olmayı evlenmeye tercih etmektedir. Kadınların eğitim seviyeleri aynı zamanda genç kadınların işgücüne katılım oranlarını da artırmaktadır. Eğitim seviyesi yüksek gençler kendi niteliklerine göre iş aramaktadırlar. Bu doğrultuda beceri ve yeteneklerinin altında herhangi bir kalifiye işte çalışmayı 
istememektedirler. Eğitim seviyeleri düşük genç bireylerde erkeklerin kadınlardan daha fazla işsizlik olgusu kapsamında yer aldığını görmekteyiz. Eğitim seviyesi düşük genç erkekler nitelik açısından da nispi olarak daha az sınırlamalara sahip olduğundan; inşaat, fabrika, sanayi gibi iş kollarında istihdam edilebilmekte ve işgücü devir oranları eğitim seviyesi yüksek gruplara göre daha düşüktür. Eğitim seviyesi düşük genç kadınlar ise, piyasa şartlarında istihdam sağlayacakları alanlar kısıtlı olduğundan piyasa koşullarında iş bulamayacaklardır. Bu grupta yer alan bireylerin daha erken yaşlarda evliliği çalışmaya tercih ettiklerini de söyleyebiliriz. Piyasada geçici işsizlik olarak adlandırdığımız iş değiştirmelerin veya yer değiştirmelerin yükseköğrenime sahip bireylerde daha sıklıkla yaşanılması genç işsizlik oranlarının bu grup içerisinde daha yüksek orana sahip olmasına neden olabilir.

Piyasa şartları içerisinde çalışma istek ve arzusunda olan bireylerin piyasa şartlarında makul bir iş arayıp bulamaması bireylerin gelecekleri hakkında çaresizlik ve umutsuzluk içerisine girmelerine sebebiyet verecektir. İşizlik olgusu, bireylerin bu süreçte hem ekonomik hem de psikolojik açıdan belirli etkilere maruz kalmalarına yol açacaktır. İş bulamayan veya iş bulma konusunda beklentisini kaybeden genç bireyler umutsuzluk ve çaresizlik içerisinde kalacak hatta bu süreç içerisinde bunalıma sürüklenebilecektir. Geleceğinden ümitsiz ve tedirgin olan bireyler bu süreç içerisinde aynı zamanda bir diğer baskı grubu olan aile baskısıla da mücadele etmek zorundadır (Kıcır, 2010). İssizlik olgusu aynı zamanda bireyler üzerinde depresyon, öfke, umutsuzluk duygusu, psikomatik semptomlar, intihar riski, alkol madde kullanımı ve hırsızlık gibi bir takım olumsuz davranışlara yönelmelerine de neden olacaktır (Kıcır, 2017).

Bilindiği üzere bireylerin sosyal kimliklerinin kazanılmasında, toplum içerisinde saygınlık kazanmalarında ve yaşamlarını idame ettirmelerinde belirli bir işe sahip olmaları önemli bir husustur. Bu doğrultuda alınan eğitimler piyasada iş gücü arzının istihdam edilmesinde ve işgücü verimliliğinin artırılmasında önemli bir paya sahiptir (Tekin, 2015). Bu noktada üniversiteler çeşitli sektörlerde istihdam sağlayacak gençlerin temel eğitimlerini sağlayarak iş dünyasına hazırlamaktadır. Belirli nitelikte gençlerin yetiştirildiği üniversitelerin 
sayısının gün geçtikçe artması ve bu yönde üniversitelerde eğitim alan ve mezun olan kişi sayısının da artması anlamına gelecektir. Her mezun olan birey rekabeti tetikleyecek bir unsur olarak görülmektedir. Bu durum piyasa şartlarında bireylerin rekabet etmelerine ve diğerlerine nazaran bir adım önde olabilmeleri için kendilerini geliştirmelerinin gerekliliğini ortaya koymaktadır (Tektaş, 2014). Aynı nitelikte birçok bireyin işgücü niteliğinde bulunması, piyasada işsizlik kaygılarının daha da artmasına yol açabilmektedir. Bilindiği üzere üniversite yılları gençlerin kaygı ve stresle sıklıkla karşılaştıkları yıllardır. Bu durumun başlıca sebepleri arasında; yeni bir çevreye uyum süreci, geleceğe yönelik iş bulma hususunda belirsizlikler, evden ve aileden ayrı kalma gibi etkenler gösterilebilir (Deveci ve ark., 2012).

Başkaları tarafından sağlanan kaynaklar olarak bilinen sosyal destek, zorlu ya da stresi tetikleyen durumlarda bireylerin ulaşabilecekleri maddi ve manevi yardımlar olarak bilinmektedir. Sosyal desteği aynı zamanda bireylerin sosyal bir gruba bağlılık duygusunu geliştirme, yardım sağlama, korundukları ve sevildiklerine inandıkları bir sisteme bağlanma olarak açıklamak mümkündür (Özdemir, 2013). Bireylere sağlanan bu sosyal destekler, bireyler üzerindeki işsizlik kaygııını azaltıcı bir etkiye sahiptir. Çünkü bireyler bu destekler sayesinde kendilerini maddi ve manevi olarak korunmuş hissedebilmektedir.

\section{Literatür Taraması}

Tatlı (2013)'nın TRB1 bölgesinde yer alan dört ilde hane halkı reisleri üzerinde yapmış olduğu çalışma, sosyal sermayenin bireylerin istihdamları üzerinde bir etkiye sahip olup olmadığının tespitini amaçlamışır. Çalışmanın bulguları sosyal sermaye olgusunun hane halkı reislerinin istihdamı hususunda önemli bir etkiye sahip olduğunu ortaya koymuştur. Sosyal sermaye düzeyinde gerçekleşen herhangi bir artışın hane halkı reislerinin istihdam edilme olasılığını oransal olarak 1,37 kat arttırdığı tespit edilmiştir. Sosyal sermayenin iş bulma noktasında herhangi bir etkiye sahip olup olmadığını araştıran Mouw (2013)'un çalışmasında, sosyal sermayenin işgücü piyasasında çıktılar üzerindeki etkisini dört veri kümesi kullanarak ortaya koymuştur. İş bulmada iş bağlantılarının 
kullanımı istihdam sağlamanın önemli bir aracı olarak görülmüştür. Fidan ve Yurdasever (2017) 'in Meslek Yüksek Okulları'nda eğitim gören öğrenciler üzerinde yapmış oldukları çalışma, öğrencilerin sosyal sermaye profillerini tespit etmek amacıyla oluşturulmuştur. Araştırma sonucunda Meslek Yüksek Okulları'nda eğitim gören öğrencilerin sosyal sermaye düzeylerinin düşük olduğu ortaya çıkmıştır. Soyut bir kavram olarak nitelendirilen sosyal sermayenin ise ölçülmesinin güç olduğu ayrıca belirtilmiştir. Sosyal sermaye olgusu ile iş gücü piyasasını birlikte konu alan Granovetter (1973)'in ampirik çalışmasında ise, sosyal sermayenin birleşenlerinden olan sosyal ağların kullanılmasının bireylerin iş bulmalarını kolaylaştırdığı ileri sürülmüştür. Özpınar vd. (2016)'in İstanbul, İzmir ve Ankara'da farklı gelir gruplarına sahip 1110 kişi üzerinde uygulamış oldukları çalışmada, bireylerin sosyal sermaye düzeyleri karşılaştırılmıştır. Bu doğrultuda çalışma sonucunda gelir gruplarına göre sosyal sermayenin farklılık gösterdiği görülmüştür. Bourdieu'nun tabiri ile "sosyal sermaye ayrıcalıklı grupların malı" olarak belirtilmiştir. Bireylerin gelir düzeyleri arttıkça politik faaliyete olan ilgi, organizasyonlara üyelik ve sosyal ağlara katılımda artışlar olacağı ifade edilmiştir. Gelir seviyeleri yüksek olan bireylerin düşük gelir seviyesine sahip olan bireylere göre sosyal sermaye düzeylerinin daha yüksek olduğu tespit edilmiştir. Dereli ve Kabataş (2009)'ın son sınıf öğrencilerinin umutsuzluk düzeylerini ve iş bulma endişelerini belirlemek amacıyla yaptıkları çalışmanın sonucunda, son sınıf öğrencilerinin umutsuzluk seviyelerinin yüksek olduğu tespit edilmiştir. Öğrencilerin cinsiyetleri, doğum yerleri, yaş grupları, iş bulmada kullanacakları yöntem ve okudukları bölümle aralarında anlamlı bir ilişki olmadığı ve bu bağlamda öğrencilerin iş bulmaya yönelik endişeleri ve iş bulma süreleri arasında ise anlamlı bir ilişki olduğu ortaya çıkmıştır. Son sınıf öğrencilerinin mezuniyetten sonra yaşayacakları kaygı düzeylerini ve kaygılarına sebebiyet veren nedenleri belirlemek amacıyla tıp fakültesi son sınıf öğrencileri üzerinde çalışma yapan Yeniçeri vd. (2007), çalışma sonucunda öğrencilerin tıbbi konulardaki yetersizliklerinin ve pratisyen olarak çalışmalarının bu öğrenciler üzerinde kaygıya sebebiyet verdiği sonucuna varmışlardır. Ergin vd. (2016)'nin tıp fakültesi 5. ve 6. sınıf öğrencileri üzerinde yapmış oldukları çalışmada, öğrencilerin mesleki kaygı düzeyleri ve sürekli kaygılarını tetikleyen etkenleri ortaya koymak amaçlanmıştır. Çalışma 
sonucunda genel yapı itibariyle 5. ve 6. sınıf tıp fakültesi öğrencilerinin uzmanlık sınavını kazanamama, çalışma yeri sıkıntısı, acil vaka hastalarla baş edememe ve uzman doktor olamama gibi kaygılarının olduğu ortaya çıkmıştır. Bu yönde bu bireyler üzerinde mesleki ve sürekli kaygının yoğunlukla etki yarattığı sonucuna varılmıştır. İlahiyat Fakültesi öğrencilerinin durumluk ve sürekli kaygılarının seviyesini ve bu kaygıları tetikleyen etmenleri incelemek amacıyla Kaya ve Varol'un (2004) yapmış oldukları çalışma sonucunda, öğrencilerin demografik özellikleriyle kaygı düzeyleri arasında anlamlı farklılık ortaya çıkmıştır. Öğrencilerin kaygılarını etkileyen en önemli nedenlerden biride iş bulamama olarak belirtilmiştir. Kız öğrencilerde başarısızlık kaygısı ve fakülteyi bitirememe korkusunun erkek öğrencilere göre daha yoğunlukta olduğu tespit edilmiştir. Erkek öğrencilerde ise, işe girememe ve iş bulamama kaygısının kız öğrencilere göre daha yoğunlukta yaşandığı sonucuna varılmıştır. Sınıflara göre ise, anlamlı bir farklılık gözlenmemiştir. Ersoy-Kart ve Erdost (2008)'un yapmış oldukları çalışmanın amacı ise, bireylerin mezuniyetten sonra işsizliğe yönelik kaygllarını tespit etmektir. Bu doğrultuda 287 öğrenci üzerinde uygulanan araştırma sonucunda, işsizlik kaygısı arttığında üniversite öğrencilerinin özsaygılarının azaldığı sonucuna varılmıştır. Öğrencilerin babalarının eğitim durumu ile işsizlik kaygısı arasında da anlamlı bir farklılık ortaya çıkmıştır. Mezuniyeti yaklaşan bireylerin bu yönde işsizlik kaygılarının arttığı tespit edilmiştir.

\section{Metodoloji}

\subsection{Araştırmanın Amacı}

Sosyal sermaye ile işsizlik kaygısını bir bütün olarak ele alan ve bu iki değişken arasında anlamlı bir ilişki ortaya koyan bir çalışmanın olmaması bu çalışmanın yapılmasına ön ayak oluşturmuştur. Bu doğrultuda 15-24 yaş aralığında yer alan bireylerin işsizlik olgusundan fazlaca etkilenmeleri, piyasaya yeni giriş yapıyor olmaları ve tecrübe eksiklikleri nedeniyle işsizlikten en fazla etkilenen grup olarak görülmeleri bu yönde işsizlik kaygısıyla daha sıklıkla karşılaştıkları düşünülen üniversite son sınıf öğrencilerinin üzerinde böyle bir araştırma yapılmasında etken oluşturmuştur. 


\subsection{Araştırmanın Yöntemi ve Sınırlılıklar}

Araştırmada kullanılan anket verilerinin bilimsel bir araştırma için kullanılacağı anket formunda belirtilmiştir. Bu sayede katılımcıların anket sorularında gerçek görüş ve ifadelerini aktardıkları düşünülmektedir. Araştırmada nicel verilere dayalı veri toplama yöntemi olan anket yöntemi tercih edilmiştir. Araştırma örneklemi, Erzurum Atatürk Üniversitesi İktisadi ve İdari Bilimler Fakültesinde yer alan son sınıf öğrencilerini kapsamaktadır. Dağıtılan anket formunda toplamda 81 soru yer almaktadır. Bunların ilk 13'ü demografik özelliklerden oluşmaktadır. Akabinde 43 sorudan oluşan sosyal sermaye ölçeği yer almaktadır. Son olarak da 25 sorudan oluşan işsizlik kaygısı soruları ankette yer almaktadır.

\subsection{Araştırmada Kullanılan Ölçekler, Model ve Hipotezler}

Bu araştırmada kullanılan ölçeklerin cevaplandırılması için 5'li likert tipine yer verilmiştir. Kullanılan ölçeklerin değerlendirilmesi hususunda katılımcılar; 1) Kesinlikle Katılmıyorum, 2) Katılmıyorum, 3) Kararsızım, 4) Katılıyorum, 5) Kesinlikle Katılıyorum şeklinde sıralanan seçeneklerden birini tercih ederek soruları yanıtlamışlardır.

Tablo 2: Araştırmada Kullanılan Ölçekler

\begin{tabular}{|l|c|c|}
\hline \multicolumn{2}{|c|}{ Sosyal Sermaye } & Işsizlik Kaygısı \\
\hline Soru Sayısı & 43 & 25 \\
\hline Referans & $\begin{array}{c}\text { Onxy ve Bullen (2000) (ilk 34 } \\
\text { soru) ve Karabey (2009) } \\
\text { (9 soru) }\end{array}$ & Ersoy-Kart ve Erdost (2008) \\
\hline
\end{tabular}

Not: Tablo 2'de gösterilen 'Ölçekler' yazarlar tarafından ilgili referanslar üzerinden derlenmiştir.

Sosyal sermaye'nin ölçülmesinde Onxy ve Bullen (2000)'in geliştirmiş olduğu sosyal sermaye ölçe ğiyle Karabey (2009)'in çalışmasında kullanmış olduğu sosyal sermaye ölçeği birleştirilmiştir. İşsizlik kaygısının ölçülmesinde ise, Ersoy-Kart ve Erdost (2008)'un araştırmasında kullanılan işsizlik kaygısı ölçeği kullanılmıştır. Yukarıdaki bilgilerden hareketle aşağıdaki araştırma modeli ve hipotezleri oluşturulmuştur. 


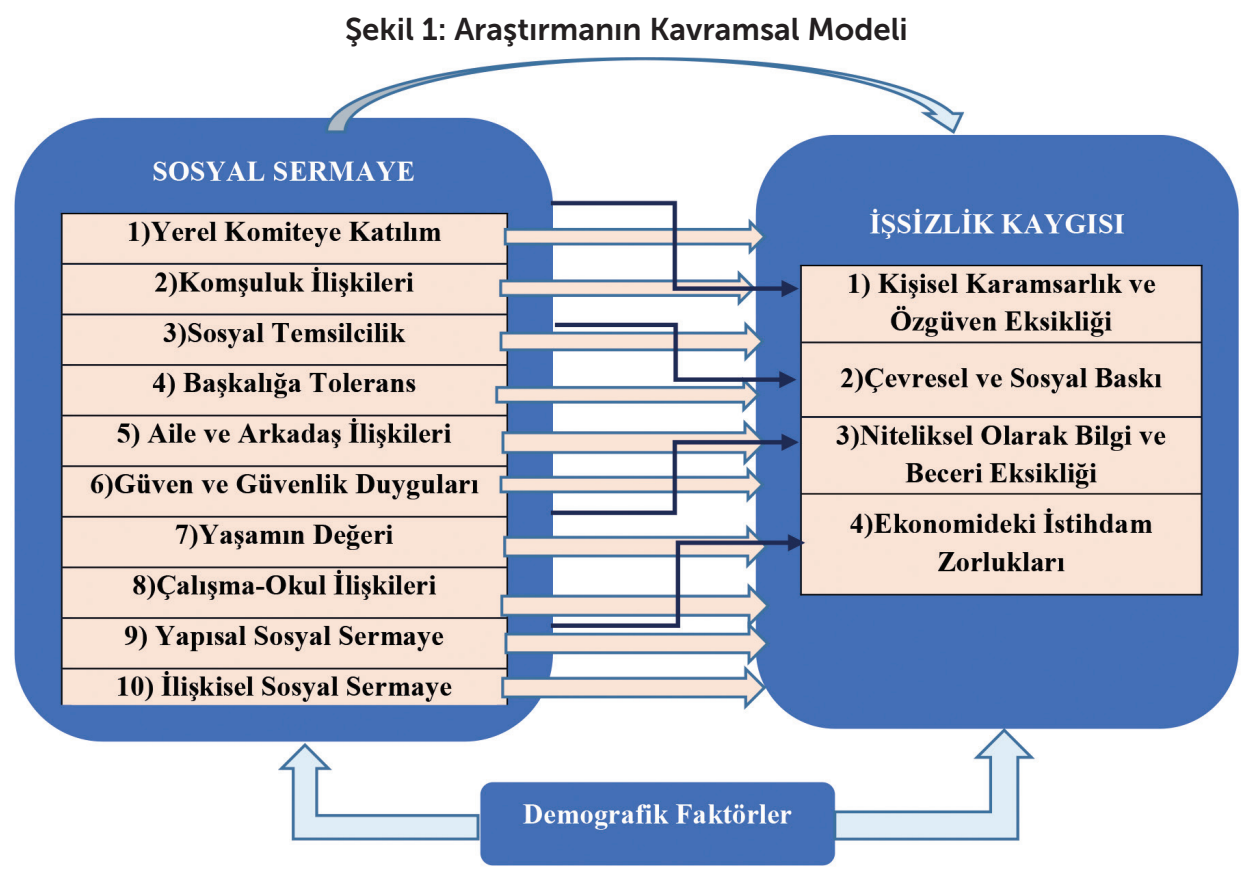

Not: Şekil 1 yazarlar tarafından oluşturulmuştur.

Şekilde de görüldügü gibi araştırma modeli iki değişken üzerine kurulmuştur. Bu iki değişkenden ilki sosyal sermayedir ve bu değişken 10 alt boyutta ele alınmıştır. Modelde yer alan ikinci değişken ise işsizlik kaygısıdır. İşsizlik kaygısı ise dört boyutta ele alınarak bu model oluşturulmuştur. Soysal sermaye ile işsizlik kaygısı arasında anlamlı bir ilişkinin olup olmadığı ve bu yönde demografik faktörlerinde bu iki olgu üzerinde herhangi bir farklılık yaratıp yaratmadığını incelemek amacıyla literatür baz alınarak model oluşturulmuştur.

\section{Hipotezler;}

$\mathbf{H}_{1}$ : Sosyal sermaye ile işsizlik kaygısı arasında anlamlı bir ilişki vardır.

$\mathbf{H}_{\mathbf{2}}$ : Sosyal sermaye ile işsizlik kaygısının alt boyutları arasında anlamlı bir ilişki vardir.

$\mathbf{H}_{3}$ : Sosyal sermayenin alt boyutları ile işsizlik kaygısı arasında anlamlı bir ilişki 
vardır.

$\mathbf{H}_{\mathbf{4}}$ : Bireylerin demografik özelliklerine göre sosyal sermaye ve işsizlik kaygısı düzeyleri farklılık göstermektedir.

\section{Verilerin Analizi Ve Değerlendirilmesi}

Çalışmaya katılan ve uygun bulunan 155 katılımcıdan alınan cevaplar üzerinden analiz yapılmıştır. Verilerin analizinde SPSS 22 istatistik programı kullanılmıştır. Yapılan analizler ise aşağıda açıklanmıştır.

\subsection{Araştırmaya Katılanların Demografik Özellikleri}

Ankete katılan kişilerin demografik özelliklerini belirlemek amacıyla bireylerin cinsiyetleri, yaşları, bölümleri, aile gelirleri, iş deneyim süreleri, anne ve babanın eğitim durumu ve çocuk sıraları araştırılmıştır. Bu doğrultuda elde edilen bilgiler Tablo 3'de verilmiştir.

Tablo 3: Örneklem Karakteristikleri

\begin{tabular}{|c|c|c|c|c|c|}
\hline & $\begin{array}{l}\text { Frekans } \\
\text { (F) }\end{array}$ & $\begin{array}{c}\text { Yüzde } \\
(\%)\end{array}$ & & $\begin{array}{l}\text { Frekans } \\
\text { (F) }\end{array}$ & Yüzde (\%) \\
\hline \multicolumn{3}{|c|}{ Toplam Katılımcı ( $\mathrm{N}=155)$} & \multicolumn{3}{|c|}{ Toplam Katılımcı (N=155) } \\
\hline $\begin{array}{l}\text { Cinsiyet } \\
\text { Kadın } \\
\text { Erkek }\end{array}$ & $\begin{array}{c}105 \\
50\end{array}$ & $\begin{array}{l}\% 67,7 \\
\% 32,3\end{array}$ & $\begin{array}{c}\text { Bölümünüz } \\
\text { Çeko } \\
\text { İktisat } \\
\text { Diğer }\end{array}$ & $\begin{array}{l}64 \\
68 \\
23\end{array}$ & $\begin{array}{l}\% 41,3 \\
\% 43,9 \\
\% 14,8\end{array}$ \\
\hline $\begin{array}{l}\text { Yaş } \\
21 \\
22 \\
23 \\
24 \\
25 \\
26 \\
27 \\
28\end{array}$ & $\begin{array}{c}42 \\
55 \\
36 \\
11 \\
5 \\
4 \\
1 \\
1\end{array}$ & $\begin{array}{c}\% 27,1 \\
\% 35,5 \\
\% 23,2 \\
\% 7,1 \\
\% 3,2 \\
\% 2,6 \\
\% 0,6 \\
\% 0,6\end{array}$ & $\begin{array}{c}\text { Aile Gelir } \\
500-1500 \\
1501-2500 \\
2501-3500 \\
3501-4500 \\
4501+\end{array}$ & $\begin{array}{l}32 \\
49 \\
39 \\
20 \\
15\end{array}$ & $\begin{array}{c}\% 20,6 \\
\% 31,6 \\
\% 25,2 \\
\% 12,9 \\
\% 9,7\end{array}$ \\
\hline $\begin{array}{l}\text { İş deneyim süresi } \\
\text { yok } \\
0-3 \text { ay } \\
4-6 \text { ay } \\
7-9 \text { ay } \\
10+\text { ay }\end{array}$ & $\begin{array}{c}70 \\
27 \\
16 \\
5 \\
37\end{array}$ & $\begin{array}{c}\% 45,2 \\
\% 17,4 \\
\% 10,3 \\
\% 3,2 \\
\% 23,9\end{array}$ & $\begin{array}{l}\text { Annenin Eğitim Durumu } \\
\text { Okur-yazar değil } \\
\text { İlköğretim } \\
\text { Lise } \\
\text { Üniversite } \\
\text { Lisansüstü }\end{array}$ & $\begin{array}{c}20 \\
104 \\
24 \\
6 \\
1\end{array}$ & $\begin{array}{l}\% 12,9 \\
\% 67,1 \\
\% 15,5 \\
\% 3,9 \\
\% 0,6\end{array}$ \\
\hline
\end{tabular}




\begin{tabular}{|l|c|c|c|c|c|}
\hline Babanın Eğitim Durumu & & & Çocuk Sırası & 50 & $\% 32,3$ \\
Okur-yazar değil & 3 & İlk & Orta & 63 & $\% 40,6$ \\
İlköğretim & 86 & $\% 55,5$ & Son & 42 & $\% 27,1$ \\
Lise & 41 & $\% 26,5$ & $\% 16,1$ & & \\
Üniversite & 25 & $\% 1$ & \\
\hline
\end{tabular}

Not: Tablo 3'de gösterilen bilgiler yazarlar tarafından oluşturulmuştur.

Araştırmaya katılan öğrenciler cinsiyetleri açısından incelendiğinde 155 kişilik örnek büyüklüğünün \% 67,7'sine denk gelen 105 kişinin kadın, \% 32,3'üne denk gelen 50 kişinin de erkek olduğu görülmüştür. Katılımcıların iş deneyim sürelerine bakıldığında; \%45,2 kişilik bir orana denk gelen 70 kişinin henüz iş deneyimine sahip olmadığı, \%23,9'luk bir orana sahip olan 37 kişinin de 10 ay ve yukarısında bir iş tecrübesine sahip olduğunu söyleyebiliriz.

\subsection{Kullanılan Ölçeklerin Güvenirliklerinin Belirlenmesi}

Sosyal sermaye ve işsizlik kaygıları açısından öğrencilerin algı düzeylerini belirlemek amacıyla Cronbach's Alpha değerlerine bakılmış ve elde edilen sonuçlar Tablo 4'te gösterilmiştir.

Tablo 4: Çalışmada Kullanılan Ölçeklerin Güvenirlik Düzeyleri

\begin{tabular}{|l|l|l|}
\hline Ölçek & Alt Boyutlar & Cronbach's Alpha \\
\hline \multirow{5}{*}{ Sosyal Sermaye } & Yerel Komiteye Katıım & 0,859 \\
\cline { 2 - 3 } & Sosyal Temsilcilik & 0,675 \\
\cline { 2 - 3 } & Güven ve Güvenlik Duyguları & 0,684 \\
\cline { 2 - 3 } & Komşuluk Ilişkileri & 0,735 \\
\cline { 2 - 3 } & Aile ve Arkadaş Ilişkileri & 0,866 \\
\cline { 2 - 3 } & Başkalığa Toleranslı Olma & 0,830 \\
\cline { 2 - 3 } & Yaşamın Değeri & 0,536 \\
\cline { 2 - 3 } & Çalışma/Okul ilişkileri & 0,814 \\
\hline & Yapısal Sosyal Sermaye & 0,674 \\
\cline { 2 - 3 } & iliş̧kisel Sosyal Sermaye & 0,674 \\
\hline
\end{tabular}




\begin{tabular}{|l|l|l|}
\hline \multirow{3}{*}{ Isşizlik Kaygısı } & Kişisel Karamsarlık ve Özgüven Eksikliği & 0,773 \\
\cline { 2 - 3 } & Çevresel ve Sosyal Baskı & 0,811 \\
\cline { 2 - 3 } & Niteliksel Olarak Bilgi ve Beceri Eksikliği & 0,794 \\
\cline { 2 - 3 } & Ekonomideki İstihdam Zorlukları & 0,832 \\
\hline Sosyal Sermaye (43) & 0,855 \\
\hline İşsizlik Kaygısı (25) & 0,913 \\
\hline
\end{tabular}

Not: Tablo 4'te gösterilenn 'Güvenirlik Düzeyleri' yazarlar tarafından hesaplanmıştır.

Tablo 4'te görüldüğü gibi kullanılan tüm ölçeklerin genel olarak güvenirlik düzeylerinin yüksek oranlarda seyir gösterdiğini görmekteyiz. Yapmış olduğumuz analizin daha sağlıklı sonuç vermesi amacıyla her sorunun katsayıya sağladığı etkiye bakılmıştır. Bu doğrultuda sosyal sermayenin alt boyutlarını oluşturan sosyal temsilcilik boyutundan st 1 ve st7 soruları atıldığında Cronbach's Alpha değerlerinin yükseldiğini ve yine aynı şekilde sosyal sermayenin alt boyutlarını oluşturan aile ve arkadaş ilişkilerinden aai3, güven ve güvenlik duygularının yer aldığı sorulardan ise ggd3 çıkarıldığında Cronbach's Alpha değerlerinde artışlar gözlenmiştir. Bir diğer değişken olan işsizlik kaygısının alt boyutlarından biri olan ekonomideki istihdam zorluklarından eiz7 sorusu çıkarıldığında da Cronbach's Alpha değerinde artış gözlenmiştir. Nitekim Cronbach's Alpha değerleri incelenirken yukarıdaki bilgiler doğrultusunda güvenirliği düşüren bazı sorular çıkartılarak Cronbach's Alpha değerlerine ulaşılmıştır. Bu doğrultuda sosyal sermayenin alt boyutları incelendiğinde Cronbach's Alpha değerleri açısından aile ve arkadaş ilişkilerinin diğer boyutlara göre daha yüksek çıktığı ve yaşamın değerinin ise diğer boyutlara göre daha düşük çıktığı görülmektedir. İşsizlik kaygısının boyutları incelendiğindeyse alt boyutların Cronbach's Alpha değerlerinden ekonomideki istihdam zorluklarının Cronbach's Alpha değerinin en yüksek orana sahip olduğu gözlenmiştir. Kişisel karamsarlık ve özgüven eksikliğinin ise diğer alt boyutlara göre daha düşük bir orana sahip olduğu göze çarpmaktadır. Yapılan analizler sonucunda Alpha değerlerine bakıldığında bu çalışmanın güvenilir olduğu ifade edilebilir. 


\subsection{Iliş̧kilerin Belirlenmesine Yönelik Korelasyon Analizi}

Bu çalışmanın analiz türünü belirlemek amacıyla verilerin normal dağılıma uygun olup olmadığı araştırılmışır. Araştırma sonucunda Sig. satırındaki veriler sınır değeri olarak kabul edilen 0,05 ten büyük olduğu için parametrik test yöntemleri kullanılmıştır. Bu durum verilerin normal dağılıma uygun olduğunu gösterdiğinden korelasyon analizi yapılırken Pearson Sıra Korelasyon katsayısına başvurulmuştur. Tablo 5 'te gösterilen korelasyon analizi incelendiğinde sosyal sermaye ile işsizlik kaygısının alt boyutları arasında aynı zamanda sosyal sermayenin alt boyutları ile işsizlik kaygısı arasında 0,99 önem düzeyinde bir ilişki olduğu görülmüştür.

Araştırmaya katılan tüm öğrencilerin sosyal sermaye ile sosyal sermayenin alt boyutları ve bu yönde işsizlik kaygısı ile işsizlik kaygısının alt boyutlarının ortalamalarına ilişkin bulgular Tablo 5 'te gösterilmektedir. Araştırmada kullanılan 5'li Likert ölçeği aralıkların eşit olduğu varsayımından hareketle, aritmetik ortalamalar için puan aralığı katsayısı 0,80 olarak bulunmuştur [Puan Aralığı $=($ En Yüksek Değer-En Düşük Değer) $/ 5=(5-1) / 5=4 / 5=0,80]$. Bu değer cevap kodlarının en düşüğü olan $1,00^{\prime}$ a, ardından ardışık olarak sonraki değerlere eklenerek değerlendirme aralıkları elde edilmiştir (Çınar ve ark., 2012). Buna göre aritmetik ortalamaların değerlendirilme aralıkları Tablo 6'daki gibidir.

Tablo 5 incelendiğinde sosyal sermaye olgusunun alt boyutlarından olan aile ve arkadaş ilişkilerinin en yüksek $(4,62)$ ortalamaya sahip olduğunu görmekteyiz. Nitekim araştırmaya katılan öğrencilerin sosyal sermaye edinimleri hususunda aile ve arkadaş ilişkilerinin çok yüksek düzeyde öneme sahip olduğu söylenebilir. Sosyal sermayenin diğer bir alt boyutu olan yerel komiteye katılımın ortalaması incelendiğinde ise, diğer alt boyutlara göre daha düşük $(2,20)$ bir ortalamaya sahip olduğu dikkatleri çekmektedir. Buna göre öğrencilerin sosyal sermaye edinimlerinde yerel komiteye katılımın bireyler açısından düşük düzeyde öneme sahip olduğu yorumu yapılabilir. Diğer bir değişken olan işsizlik kaygısının alt boyutlarından çevresel ve sosyal baskı ortalamasının diğer alt boyutlara göre daha yüksek $(3,05)$ bir orana sahip olduğu görülmektedir. Araştırmaya katılan öğrencilerin çevresel ve sosyal baskı noktasında kararsız düzeyde olduklarını ifade edebiliriz. 


\begin{tabular}{|c|c|c|c|c|c|c|c|c|c|c|c|c|c|c|c|c|}
\hline ને & & & & & & & & & & & & & & & & $\rightarrow$ \\
\hline$\stackrel{\bullet}{\bullet}$ & & & & & & & & & & & & & & & -1 & 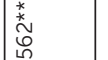 \\
\hline$\stackrel{\sim}{\sim}$ & & & & & & & & & & & & & & $\neg$ & \begin{tabular}{|l}
$*$ \\
\multirow{2}{*}{} \\
0 \\
0
\end{tabular} & $\begin{array}{l}* \\
\exists \\
\end{array}$ \\
\hline$\underset{J}{+}$ & & & & & & & & & & & & & $\rightarrow$ & 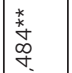 & 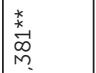 & 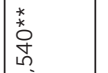 \\
\hline$\stackrel{M}{\rightarrow}$ & & & & & & & & & & & & $\neg$ & f & $\underset{\sim}{\stackrel{\infty}{\sim}}$ & 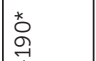 & 兽 \\
\hline$\approx$ & & & & & & & & & & & $\rightarrow$ & 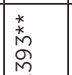 & 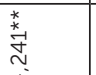 & 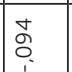 & $\begin{array}{l}* \\
\stackrel{*}{6} \\
-1\end{array}$ & 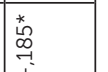 \\
\hline$\exists$ & & & & & & & & & & $\neg$ & 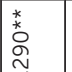 & 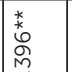 & 总 & \begin{tabular}{l}
$*$ \\
\multirow{2}{*}{} \\
$\stackrel{0}{0}$ \\
\hdashline-1
\end{tabular} & 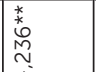 & \begin{tabular}{|l|l}
$*$ \\
0 \\
\hdashline \\
\hdashline \\
\hdashline
\end{tabular} \\
\hline$a$ & & & & & & & & & -1 & 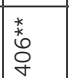 & 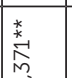 & 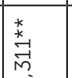 & 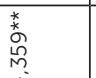 & 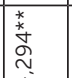 & 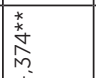 & 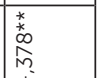 \\
\hline$\infty$ & & & & & & & & $\rightarrow$ & $\begin{array}{l}\infty \\
\exists \\
\exists\end{array}$ & 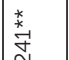 & $\underset{\sim}{*}$ & $\underset{\sim}{\sim}$ & J̊ & 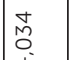 & त् & $\stackrel{0}{7}$ \\
\hline$\wedge$ & & & & & & & -1 & 吕 & 范 & $\underset{⿱}{*} \underset{\sim}{*}$ & ò & \begin{tabular}{l}
$*$ \\
\multirow{2}{*}{} \\
\multirow{\sigma}{*}{}
\end{tabular} & Mo & $\begin{array}{l}m \\
\infty \\
0 \\
0\end{array}$ & $\underset{7}{7}$ & $\tilde{\Xi}$ \\
\hline 0 & & & & & & - & $\begin{array}{l}\stackrel{*}{*} \\
\stackrel{0}{0}\end{array}$ & ले. & 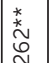 & 莡 & $\stackrel{*}{\stackrel{*}{N}} \underset{\sim}{\sim}$ & \begin{tabular}{l}
$*$ \\
\multirow{2}{*}{} \\
\multirow{2}{*}{}
\end{tabular} & 冓 & $\underset{\exists}{\nexists}$ & & 摖 \\
\hline in & & & & & -1 & \begin{tabular}{|l|}
\multirow{2}{*}{} \\
\multirow{2}{*}{} \\
$\stackrel{2}{2}$ \\
Non
\end{tabular} & $\begin{array}{l}\infty \\
\stackrel{\infty}{\circ} .\end{array}$ & 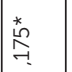 & 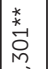 & 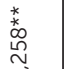 & 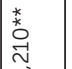 & 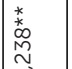 & 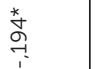 & 莡 & \begin{tabular}{l}
$*$ \\
\multirow{2}{*}{} \\
7
\end{tabular} & 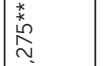 \\
\hline$\nabla$ & & & & $\dashv$ & ठ̊. & 荵 & 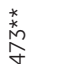 & 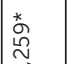 & 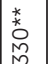 & 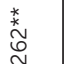 & 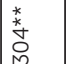 & \begin{tabular}{l}
$*$ \\
\multirow{2}{*}{} \\
0 \\
0
\end{tabular} & $\hat{o}$ & $\underline{\tilde{N}}$ & $\underset{7}{\stackrel{9}{r}}$ & 音 \\
\hline m & & & $\rightarrow$ & $\stackrel{m}{o}$ & 우 & $\begin{array}{l}\infty \\
0 \\
0\end{array}$ & $\underset{7}{\stackrel{7}{?}}$ & $\begin{array}{l}n \\
\varnothing \\
0\end{array}$ & $\underset{\mathrm{M}}{\mathrm{M}}$ & 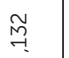 & \begin{tabular}{l}
\multirow{N}{*}{} \\
$\stackrel{N}{N}$ \\
$\sim$
\end{tabular} & Oे & $\begin{array}{l}\text { * } \\
\stackrel{2}{\neg}\end{array}$ & $\begin{array}{l}\infty \\
\stackrel{2}{0} \\
0,\end{array}$ & 옹 & $\stackrel{\sim}{\underset{\sim}{\sim}}$ \\
\hline$\sim$ & & $\rightarrow$ & $\begin{array}{l}t \\
\hat{O}\end{array}$ & ָే & 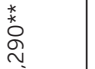 & g & $\underset{\hat{0}}{\tilde{0}}$ & $\begin{array}{l}0 \\
\tilde{N} \\
0\end{array}$ & \begin{tabular}{|l|}
$*$ \\
\multirow{2}{*}{} \\
$\vec{\gamma}$
\end{tabular} & \begin{tabular}{l} 
* \\
o \\
\multirow{N}{N}{}
\end{tabular} & \begin{tabular}{l}
$*$ \\
$\stackrel{*}{\circ}$ \\
\hdashline
\end{tabular} & 국 & 是 & \begin{tabular}{l}
$*$ \\
\multirow{2}{*}{} \\
$\infty$ \\
$\infty$
\end{tabular} & \begin{tabular}{l}
$*$ \\
\multirow{2}{*}{} \\
$\stackrel{N}{N}$
\end{tabular} & 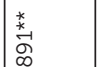 \\
\hline-1 & $\rightarrow$ & \begin{tabular}{l}
$*$ \\
\multirow{2}{*}{} \\
$\stackrel{N}{\sim}$ \\
$\sim$
\end{tabular} & 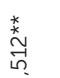 & 贲 & 莡 & 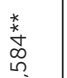 & 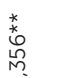 & 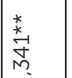 & 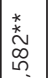 & \begin{tabular}{l}
$*$ \\
\multirow{2}{*}{0} \\
0 \\
0
\end{tabular} & 㮒 & 莡 & 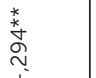 & 䒫 & 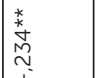 & 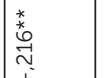 \\
\hline 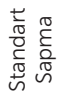 & $\begin{array}{l}\underset{N}{\mathbb{N}} \\
\underset{\forall}{\forall}\end{array}$ & $\begin{array}{l}\stackrel{o}{M} \\
\vec{N} \\
\stackrel{N}{N}\end{array}$ & $\begin{array}{l}\infty \\
\stackrel{\infty}{N} \\
\stackrel{M}{\sigma} \\
\sigma\end{array}$ & $\begin{array}{l}\stackrel{0}{ } \\
\infty \\
\infty \\
.\end{array}$ & $\begin{array}{l}\underset{\Omega}{\widetilde{\alpha}} \\
\underset{\infty}{\infty}\end{array}$ & 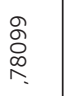 & $\begin{array}{l}\stackrel{0}{0} \\
\stackrel{0}{0} \\
\hat{6}\end{array}$ & 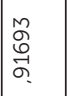 & \begin{tabular}{|l|} 
\\
$\tilde{w}$ \\
$\infty$ \\
0 \\
$\alpha$ \\
$\alpha$ \\
\end{tabular} & 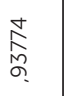 & 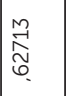 & $\begin{array}{l}\hat{E} \\
0 \\
0\end{array}$ & 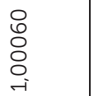 & 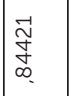 & $\begin{array}{l}0 \\
\infty \\
\infty \\
\infty \\
\infty \\
\infty\end{array}$ & $\begin{array}{l}\text { Oे } \\
\text { M } \\
\text { M. } \\
\infty\end{array}$ \\
\hline \multirow[t]{2}{*}{$\begin{array}{l}\frac{\pi}{2} \\
\frac{\pi}{\pi} \\
\frac{\pi}{\pi} \\
0\end{array}$} & $\begin{array}{l}\stackrel{ }{\mathcal{M}} \\
\underset{\sim}{\sim} \\
M\end{array}$ & $\begin{array}{l}0 \\
\stackrel{7}{2} \\
\overrightarrow{7} \\
\text { m. }\end{array}$ & 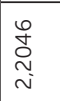 & $\begin{array}{l}\infty \\
\stackrel{\infty}{7} \\
\underset{\forall}{*}\end{array}$ & $\begin{array}{l}\infty \\
0 \\
\circ \\
0 \\
\text { Mi }\end{array}$ & $\begin{array}{l}\tilde{N} \\
0 \\
\stackrel{N}{n} \\
M\end{array}$ & $\begin{array}{l}\stackrel{0}{\mathbb{N}} \\
\underset{\sigma}{*}\end{array}$ & 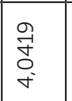 & \begin{tabular}{|l|}
0 \\
0 \\
0 \\
0 \\
$\dot{m}$ \\
$\dot{m}$
\end{tabular} & $\begin{array}{l}8 \\
8 \\
0 \\
\dot{0} \\
\text { mi }\end{array}$ & 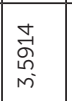 & 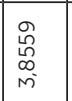 & $\begin{array}{l}\tilde{N} \\
\tilde{Y} \\
0 \\
\dot{m}\end{array}$ & \begin{tabular}{|l|}
$\infty$ \\
0 \\
0 \\
0 \\
nj \\
ni
\end{tabular} & 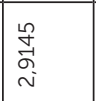 & $\begin{array}{l}\tilde{N} \\
\hat{S} \\
\text { n. } \\
\text { n. }\end{array}$ \\
\hline & 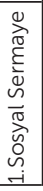 & 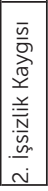 & 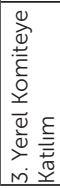 & 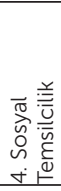 & 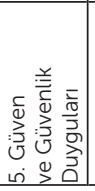 & 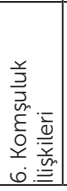 & 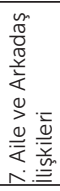 & 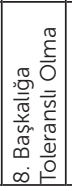 & 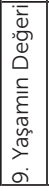 & 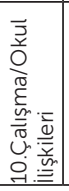 & 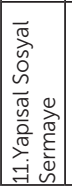 & 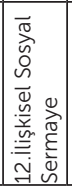 & 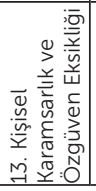 & 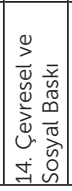 & 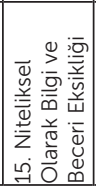 & 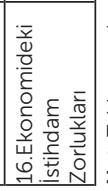 \\
\hline
\end{tabular}


Tablo 6: Aritmetik Ortalamaların Değerlendirilme Aralığı

\begin{tabular}{|l|l|}
\hline Aralık & Aralık Değeri \\
\hline $1,00-1,80$ & Çok Düşük \\
\hline $1,81-2,60$ & Düşük \\
\hline $2,61-3,40$ & Orta \\
\hline $3,41-4,20$ & Yüksek \\
\hline $4,21-5,00$ & Çok Yüksek \\
\hline
\end{tabular}

Not: Tablo 6'da gösterilen 'Değerlendirme Aralığı' (Çınar ve ark., 2012)'dan alınmıştır.

İssizlik kaygısı alt boyutlarından en düşük ortalama ise $(2,91)$ niteliksel olarak bilgi ve beceri eksikliği boyutuna aittir. Bu doğrultuda öğrencilerin niteliksel olarak bilgi ve beceri eksikliği açısından kararsız düzeyde oldukları yorumu yapılabilir. Genel yapı itibariyle sosyal sermaye alt boyutlarının ortalamalarının oransal olarak yüksek ve nispeten orta düzeyde seyir gösterdiği görülür. Bu yönde işsizlik kaygısı ortalamalarının da orta düzeyde dağılım gösterdiği göze çarpar. Bu doğrultuda araştırmaya katılan öğrencilerin sosyal sermaye ortalamalarının yüksek düzeyde olduğu ve sosyal sermaye edinimlerinin bu doğrultuda yüksek olacağı düşünülmektedir. İşsizlik kaygısı ortalamalarının ise orta düzeyde olması son sınıf öğrencilerinin mezuniyetleriyle birlikte gelecekleriyle ilgili işsizlik kaygılarının da orta düzeyde yaşanacağının göstergesidir.

Tablo 5 'ten de görüldüğü üzere sosyal sermaye ile işsizlik kaygısı arasında $(p<0,01 r=-, 239)$ ters yönlü ve anlamlı bir ilişkinin olduğu anlaşılmaktadır. Bu doğrultuda öğrencilerin sosyal sermayeleri arttıkça gelecekleriyle ilgili işsizlik kaygılarının tersi doğrultuda azalacağı yorumu yapılabilir. İlgili tablodan da görüldüğü gibi sosyal sermaye ile işsizlik kaygısı arasında anlamlı bir ilişki ortaya çıkmış ve $\mathbf{H 1}$ hipotezi kabul edilmiştir. Aynı zamanda sosyal sermaye ile işsizlik kaygısının alt boyutlarından olan kişisel karamsarlık ve özgüven eksikliği arasında $(p<0,01 r=-, 294)$ ters yönlü ve anlamlı ilişki ortaya çıkmıştır. Akabinde sosyal sermaye ile işsizlik kaygısının alt boyutlarından bir diğeri olan çevresel ve sosyal baskı arasında ( $p<0,05 r=-, 103)$ ters yönlü bir ilişki olduğu göze çarparken, yine sosyal sermaye ile işsizlik kaygısının alt boyutlarından olan niteliksel olarak bilgi ve beceri eksikliği $(p<0,01 \mathrm{r}=-, 234)$ ve ekonomideki istihdam zorlukları $(p<0,01 r=-, 216)$ arasında da ters yönlü ve anlamlı bir ilişki olduğu görülmektedir. Tablodaki sonuçlardan da görüldüğü üzere sosyal sermaye ile işsizlik kaygısının alt 
boyutları arasında anlamlı bir ilişki ortaya çıkmıştır. Nitekim öğrencilerin sosyal sermayeleri arttıkça bireylerin kişisel karamsarlık ve özgüven eksikliklerinde azalma olacağını ve çevrelerinden gördükleri sosyal baskılarda da düşüşler olacağını ifade edebiliriz. Sonuç olarak sosyal sermaye ile işsizlik kaygısının alt boyutları arasında anlamlı bir ilişkinin ortaya çıkması $\mathbf{H} \mathbf{2}$ hipotezinin kabul edildiğinin göstergesidir.

Sosyal sermayenin alt boyutları ile işsizlik kaygısı arasındaki ilişki incelendiğinde ise; sosyal sermayenin alt boyutlarından olan güven ve güvenlik duygularının işsizlik kaygısıyla arasında ( $p<0,01 r=-, 290)$, ters yönlü ve anlamlı bir ilişki olduğu akabinde sosyal sermayenin alt boyutlarından olan yaşamın değeriyle işsizlik kaygısı arasında $(p<0,01 r=-, 419)$ da ters yönlü ve anlamlı bir ilişki olduğu gözlenmiştir. Bu doğrultuda sosyal sermayenin diğer alt boyutlarından olan çalışma/okul ilişkilerinin $(p<0,01 r=-, 218)$ ve yapısal sosyal sermayenin de ( $p<0,05 r=-, 196)$ işsizlik kaygısıyla arasında ters yönlü bir ilişkiye sahip olduğunu ifade edebiliriz. Sonuç olarak sosyal sermayenin alt boyutlarında yaşanacak herhangi bir artışın bireylerin gelecekleri hakkında yaşayacakları işsizlik kaygıları üzerinde ters yönlü bir etki yaratarak kaygılarının düşmesine ve geleceklerine daha umutla bakmalarına etken oluşturabileceği yorumunu yapabiliriz. Nitekim bu doğrultuda sosyal sermayenin alt boyutları ile işsizlik kaygısı arasında anlamlı bir ilişkinin çıkması $\mathbf{H 3}$ hipotezinin kabul edilebilir olduğunu göstermektedir.

Hipotez sonuçlarında işsizlik kaygısı alt boyutlarından kişisel karamsarlık ve özgüven eksikliğinin diğer alt boyutlara göre yüksek çıkmasının altında yatan nedene bakıldığında; bireylerin çevrelerinden gördükleri baskı, piyasa şartlarında nitelik ve becerileri doğrultusunda iş bulamayışları veya öğrencilerin henüz iş deneyimine sahip olmamaları gibi sebeplerden ötürü bireyler psikolojik açıdan karamsarlık içerisine girecek ve kendilerine olan özgüvenlerini yitireceklerdir. Araştırmaya katılan öğrencilerin son sınıf olması ve henüz iş tecrübelerinin olmamaları veya iş bulma noktasında sosyal sermaye edinimlerinin bulunmaması gelecekleriyle ilgili karamsarlığa kapılmalarına ve özgüvenlerini yitirmelerine zemin oluşturmaktadır. Sosyal sermaye alt boyutlarından olan yaşamın değerinin diğer alt boyutlara göre yüksek çıkmasının nedeni incelendiğinde ise; bireylerin yaşamış oldukları hayat içerisinde kendilerinin ve yaşamış olduklarının değerli 
görülmesinden geçmektedir. Bu doğrultuda hayat içerisinde bireylerin yaşam değeri arttıkça sosyal sermayeleri artacak sosyal sermayesi artan bireyler geleceğe daha umutla bakacak ve işsizlik kaygıları daha da azalacaktır.

Bireylerin demografik özelliklerine göre sosyal sermaye ve işsizlik kaygısı düzeylerinin farklılık gösterip göstermediğini incelemeden önce araştırma verilerinin normal dağılıma uygun olup olmadığını ortaya koymak amacıyla normallik testi yapılmış ve verilerin normal dağılıma uygun olduğu anlaşılmıştır. Bu doğrultuda farkındalık testleri olarak T Testi ve varyans analizi yapılmıştır.

Tablo 7: Cinsiyet Değişkenine Göre İşsizlik Kaygısı Farklılıkları

\begin{tabular}{|l|c|c|c|c|c|}
\hline & Cinsiyet & $\mathbf{N}$ & Ortalama & $\mathbf{t}$ & $\mathbf{p}$ \\
\hline \multirow{2}{*}{$\begin{array}{l}\text { Işsizlik } \\
\text { Kaygısı }\end{array}$} & Kadın & 105 & 3,3039 & 2,890 & \multirow{2}{*}{, 004} \\
\cline { 2 - 4 } & Erkek & 50 & 2,9539 & 2,804 \\
\hline
\end{tabular}

Not: Tablo 7'de gösterilen 'İşsizlik Kaygısı Farklııkları' yazarlar tarafından hesaplanmıştır.

Cinsiyet farklılığının işsizlik kaygısını etkileyip etkilemediğini analiz etmek amacıyla t testi uygulanmıştır. Uygulanan $T$ testi sonucuna göre Sig. değeri 0,05'ten küçük olduğu ortaya çıkmıştır. Sig. değeri 0,05'ten küçük olduğundan dolayı cinsiyet ile işsizlik kaygısı arasında $p<0,05$ düzeyinde anlamlı bir ilişki olduğu sonucuna varılmıştır. Kadınların işsizlik kaygısı algılarının ise erkeklere göre yüksek olduğu görülmüştür. Kadınların işgücü piyasasında her sektörde çalışma alanı bulamıyor olmalarının kadınların gelecekleriyle ilgili işsizlik kaygısı duymalarında ekili olduğunu söyleyebiliriz.

Tablo 8: İş Deneyimi Değişkenine Göre İşsizlik Kaygısı Farklılıkları

\begin{tabular}{|c|c|c|c|c|c|}
\hline İş Deneyimi & Frekans & Ortalama & $\begin{array}{l}\text { Farklı Gruplar } \\
\text { (LSD'ye göre) }\end{array}$ & $F$ & $p$ \\
\hline Yok & 70 & 3,29 & \multirow{5}{*}{$\begin{array}{c}\text { Yok \& } 10 \text { ay+ } \\
0-3 \text { ay \& } 10 \text { ay+ } \\
4-6 \text { ay \& } 10 \text { ay+ }\end{array}$} & \multirow{5}{*}{2,689} & \multirow{5}{*}{,033 } \\
\hline $0-3$ ay & 27 & 3,31 & & & \\
\hline $4-6$ ay & 16 & 3,35 & & & \\
\hline 7-9 ay & 5 & 2,89 & & & \\
\hline 10 ay + & 37 & 2,89 & & & \\
\hline
\end{tabular}

Not: Tablo 8'de gösterilen 'İşsizlik Kaygısı Farklııkları' yazarlar tarafından hesaplanmıştır. 
Yapılan tek yönlü varyans analizi sonucunda iş deneyimi değişkenine göre işsizlik kaygısı düzeyinin 0,05 anlamlılık düzeyinde istatistiki açıdan anlamlı bir farklılık gösterdiği tespit edilmiştir $(p=0,033<0,05)$. Bu doğrultuda farklı olan grupları tespit etmek amacıyla LSD testi uygulanmıştır. Analiz sonucuna göre, işsizlik kaygısının iş deneyimi olmayan ve 10 ay ve yukarısında iş deneyimine sahip olan öğrenciler arasında anlamlı bir farklılık gösterdiği sonucuna varılmıştır. Aynı doğrultuda 0-3 ay düzeyinde iş tecrübesi olan öğrenciler ile 10 ay ve üzeri iş deneyimine sahip olan öğrenciler arasında da anlamlı bir farklılık tespit edilmiş. Nitekim anlamlı farklılık gösteren diğer gruplar 4-6 ay ve 10 ay+ olanlardır. 4-6 ay iş tecrübesine sahip olan öğrencilerle 10 ay ve yukarısında iş deneyimine sahip öğrenciler arasında istatistiksel anlamda anlamlı bir farklılık tespit edilmiştir. Bu sonuçlar neticesinde iş deneyimi olan öğrencilerin iş deneyimi olmayan öğrencilere oranla daha düşük işsizlik kaygısı yaşadıklarını ifade edebiliriz.

Tablo 9: Cinsiyet Değişkenine Göre Sosyal Sermaye Farklılıkları

\begin{tabular}{|l|c|c|c|c|c|}
\hline & Cinsiyet & $\mathbf{N}$ & Ortalama & $\mathbf{t}$ & $\mathbf{p}$ \\
\hline \multirow{2}{*}{ Sosyal Sermaye } & Kadın & 105 & 3,3641 & \multirow{2}{*}{$-2,584$} & \multirow{2}{*}{011} \\
\cline { 2 - 4 } & Erkek & 50 & 3,5467 & & \\
\hline
\end{tabular}

Not: Tablo 9'da gösterilen 'Sosyal Sermaye Farklılıkları' yazarlar tarafından hesaplanmıştır.

Tablo 9'da yer alan $t$ testi sonuçlarına göre, öğrencilerin cinsiyetleri ile sosyal sermaye algıları arasında anlamlı bir farklılık ortaya çıkmışır $(p=0,011<0,05)$. Bu doğrultuda erkeklerin sosyal sermaye algılarının kadınlara oranla yüksek olduğu yorumu yapılabilir.

Tablo 10: İş Bulma Noktasında Akraba Değişkenine Göre Sosyal Sermaye Farklılıkları

\begin{tabular}{|l|c|c|c|c|c|}
\hline & Akraba & $\mathbf{N}$ & Ortalama & $\mathbf{t}$ & $\mathbf{p}$ \\
\hline \multirow{2}{*}{ Sosyal Sermaye } & $\operatorname{var}$ & 61 & 3,5074 & \multirow{2}{*}{2,041} & \multirow{2}{*}{, 043} \\
\cline { 2 - 4 } & yok & 94 & 3,3682 & 2,042 \\
\hline
\end{tabular}

Not: Tablo 10'da gösterilen 'Sosyal Sermaye Farklııkları' yazarlar tarafından hesaplanmıştır.

Tablo 10'da ise öğrencilerin iş bulma noktasında bireylere yardımcı olabilecek herhangi bir akrabalarının olup olmaması durumunun bireylerin sosyal sermayeleri üzerinde bir farklılık yaratıp yaratmadığı incelenmiştir. Bu yönde bireylerin iş 
bulma noktasında akrabaya sahip olup olmamalarıla sosyal sermaye algıları arasında anlamlı bir farklılık ortaya çıkmıştır. İş bulma noktasında akrabası olan bireylerin sosyal sermaye algılarının iş bulma noktasında akrabası olmayan bireylere göre daha yüksek oranlarda seyir gösterdiği görülür. Gerçekleştirilen farklılık analizleri neticesinde öğrencilerin demografik özelliklerine göre sosyal sermaye ve işsizlik kaygısı düzeyleri farklılık gösterdiği yorumu yapılabilir. Yani H4 hipotezi kabul edilmektedir.

\section{Sonuç}

Illgili literatürde geniş yer bulan konulardan biri de sosyal sermaye düzeyleri insanların işsizlik kaygıları üzerinde bir etkide bulunmakta mıdır sorusuna cevap aramaktadır. Sosyal sermaye ile işsizlik kaygısı arasındaki ilişkiyi tespit etmek amacıyla oluşturulan bu çalışmada geri dönüş alınan 155 anket analiz edilmiş ve analiz sonucunda araştırmanın değişkenlerinden olan sosyal sermaye ile işsizlik kaygısı arasında ters yönlü ve anlamlı bir ilişki olduğu ortaya çıkmışır. Analiz sonuçları araştırmada kullanılan dört hipotezin dördünü de desteklemiştir. Öğrencilerin demografik özelliklerine göre sosyal sermaye ve işsizlik kaygısı düzeyleri farklılık göstermiş̧ir. Bu bağlamda kadınların işsizlik kaygısı algılarının erkeklere göre yüksek bir orana sahip olduğu gözlenmiştir. Nitekim kadınların işgücü piyasasında her sektörde çalışma alanı bulamıyor olmalarının kadınların gelecekleriyle ilgili işsizlik kaygısı duymalarında etkili olduğu yorumu yapılabilir. Işs bulma noktasında akrabası olan bireylerin sosyal sermaye algılarının iş bulma noktasında akrabası olmayan bireylere göre daha yüksek bir orana sahip olduğu görülmüştür.

Sonuç olarak öğrencilerin sosyal sermaye edinimlerinin artırılması hususunda, sosyal ağlara ulaşmada etkili kanalların oluşturulması, üniversitelerde sosyal sermaye ile ilgili derslerin konulması, çeşitli kuruluşlarla iş birliği içerisinde çalışarak öğrencilerin sosyal sermaye algılarının artırılması, üniversite bağlamında kulüpler aktifleştirilerek çeşitli kulüp faaliyetleri ile öğrencilerinin sosyal ilişki ağlarının genişlemesini sağlamak, bölgesel farklılıkları ortadan kaldırarak öğrencilerin sosyal çevrelerinin genişletilmesi ve daha aktif bir şekilde güven ve sosyal ilişkilerin 
oluşturulması, bireylerin yaşam değerlerini artıracak faaliyetlerde bulunmalarını sağlamak, sosyal sermayeye olan ilginin canlı tutulmasına yönelik olarak STK ve üniversiteler ile birlikte çalışmalar yürütülmesi bireylerin sosyal sermaye edinimlerini artıracaktır. Bu doğrultuda sosyal sermayesi artan bireylerin işsizlik kaygılarının azalacağı yorumunu yapabiliriz. Bu bağlamda yapılacak diğer çalışmalarda, devlet üniversiteleri ile özel üniversiteler karşılaştırılarak bu iki değişken arasındaki farklılıklar ortaya konulabilir. Yapılacak sonraki çalışmalarda, sosyal sermaye ile işsizlik kaygısına ilaveten sosyal sermaye ile pozitif yönlü bir ilişkisi olan istihdamı da bir arada kullanarak aradaki farklılıkların ortaya konulması literatür açısından faydalı olacağı düşünülmektedir.

Finansal Destek: Yazarlar bu çalışma için finansal destek almamışlardır.

\section{Kaynaklar}

Bourdieu, P. (1986). "The Forms of Capital", Richardson, J. G., (edt.) in Handbook of Theory and Research for the Sociology of Education (1986), Westport, CT: Greenwood, pp. 241-258.

Büyükilikmen, A. Y. (2015). Sosyal Sermaye ve Ölçülmesi/Social Capital and Measurement. Selçuk Üniversitesi Sosyal ve Teknik Araştırmalar Dergisi, 10, 45-52.

Coşan, B., Şahin, Ş. ve Yörübulut, M. Ç. (2017). Küresel Ekonominin Kronik Sorunsalı Genç İşsizlik: Türkiye-Güney Avrupa (İspanya, İtalya, Portekiz, Yunanistan) Ülkelerinin Karşılaştırması. Gazi Üniversitesi Iktisadi ve Idari Bilimler Fakültesi Dergisi, Gazi Akademi Genç Sosyal Bilimciler Sempozyumu Özel Sayısı, 220-238.

Çınar, O., Yavuz, S. ve Aslan, İ. (2012). Akademisyenlerin İnternet Bankacılığı Hakkındaki Tutum, Düşünce Ve Davranışları: Erzincan Üniversitesi Örneği. Selçuk Üniversitesi IIiBF Sosyal ve Ekonomik Araştırmalar Dergisi, 23, 103-124.

Dereli, F. ve Kabataş, S. (2009). Sağlık Yüksekokulu Son Sınıf Öğrencilerinin İş Bulma Endişeleri ve Umutsuzluk Düzeylerinin Belirlenmesi. Yeni Tıp Dergisi, 26, 31-36.

Deveci, S. E., Çalmaz, A. ve Açık, Y. (2012). Doğu Anadolu'da Yeni Açılan Bir Üniversitenin Öğrencilerinde Kaygı Düzeylerinin Sağlık, Sosyal ve Demografik Faktörler Ille Illişkisi. Dicle Tıp Dergisi, 39(2), 189-196.

Erdayı, A. U. (2009). Dünyada Genç İşsizliği Sorununun Çözümüne Yönelik Ulusal Politikalar ve Türkiye. Çalışsma ve Toplum, 3, 133-162.

Ergin, A., Uzun, S. U. ve Topaloğlu, S. (2016). Pamukkale Üniversitesi Tıp Fakültesi 5. ve 6. Sınıf Öğrencilerinin Sürekli Kaygı ve Mesleki Kaygı Düzeyleri ve Bunları Etkileyen Etkenler. Muğla Sıtkı Koçman Üniversitesi Tıp Dergisi, 3(3), 16-21. 
Ersoy Kart, M. ve Erdost, H. E. (2008). Unemployment worries among Turkish university students. Social Behavior and Personality: An international Journal, 36, 275-288.

Fidan, Y. ve Yurdasever, E. (2017). Meslek Yüksekokulu Öğrencilerinin Sosyal Sermaye Profilleri Üzerine Bir Araştırma: Ordu Üniversitesi Sosyal Bilimler Meslek Yüksekokulu Örneği. Manisa Celal Bayar Üniversitesi Sosyal Bilimler Dergisi, 15(1), 219-248.

Fitzgerald, S. M. (1997). The Relationship Between Anxiety and Statistics Achievement: A MetaAnalysis. (Doctoral dissertation). Toledo: Toledo University.

Fukuyama, F. (2001). Social Capital, Civil Society and Development. Third World Quarterly, 22(1), 7-20.

Granovetter, M. S. (1973). The Strength of Weak Ties. American Journal of Sociology, 78, 1360-1380.

Hanifan, L. J. (1916). The Rural School Community Center. Annals of the American Academy of Political and Social Science, 67, 130-138.

Işığıçok, Ö. (2017). Istihdam ve Işsizlik (3. bs). Bursa: Dora Basım.

Işıı, V. (2016). Türkiye'de Genç İşsizliği ve Genç Nüfusta Atalet. HAK-iş Uluslararası Emek ve Toplum Dergisi, 11, 131-145.

Karabey, C. N. (2009), Girişimcilikte Fırsat Tanımlamayı Etkileyen Bireysel Faktörler: Beşeri ve Sosyal Sermaye Perspektifi. (Doktora Tezi). Atatürk Üniversitesi Sosyal Bilimler Enstitüsü, Erzurum.

Karagül, M. (2015). Sosyal Sermaye ve Ibn-i Haldun'un Asabiyet Düşüncesi, 1st International Congress on Applied Sciences: Social Capital - UUBK, Konya-Türkiye.

Karagül, M. ve Masca, M. (2005). Sosyal Sermaye Üzerine Bir İnceleme. Ekonomik ve Sosyal Araştırmalar Dergisi, 1, 37-52.

Kaya, M. ve Varol, K. (2004). Illahiyat Fakültesi Öğrencilerinin Durumluk-Sürekli Kaygı Düzeyleri ve Kaygı Nedenleri (Samsun Örneği). Ondokuz Mayıs Üniversitesi Illahiyat Fakültesi Dergisi, 17(17), $31-63$.

Kıcır, B. (2010). Üniversite Son Sınıf Öğrencilerinde İşsizlik Kaygısı: Psikolojik Etmenler Açısından Bir Inceleme. (Yüksek Lisans Tezi). Ankara Üniversitesi Sosyal Bilimler Enstitüsü, Ankara.

Kıcır, B. (2017). Eğitimli Genç İşsizliği Üzerinden İşsizlik Kaygısına Bir Bakış. Çalışma ve Toplum, 3, 1369-1396.

Kitapcı, İ. (2015). Motivasyonel Bir Güç Olarak Sosyal Sermaye Kavramı ve Rasyonalitesi. Hukuk ve iktisat Araştırmaları Dergisi, 7(1-2), 11-36.

Mouw, T. (2003). Social Capital and Finding a Job: Do Contacts Matter?. American Sociological Review, 68(6), 868-898.

Niggemeyer-Hall, A. E. (2001). Family Interaction Factors \& Anxiety in Adolescent Females. (Doctoral dissertation). Seattle: Seattle Pacific University.

Onyx, J., \& Bullen, P. (2000). Measuring Social Capital in Five Communities. The Journal of Applied Behavioral Science, 36(1), 23-42.

Özdemir, İ. (2013). Aile Yanında Yaşayan ve Ailesinden Ayrı Yaşayan Üniversite Öğrencilerinin Algılanan Sosyal Destek, Stresle Başa Çıkma Tarzları, Kaygı Düzeyleri ve Psikolojik Belirtiler Açısından Karşılaştırılması. (Yüksek Lisans Tezi). Hacettepe Üniversitesi Sosyal Bilimler Enstitüsü, Ankara. 
Özpınar, Ş., Özpınar, Ö., Çondur, F. ve İkizoğlu, F. (2016). Türkiye'de Üç Büyük Kentte Sosyal Sermayenin Bourdieu'nün Kavramsallaştırması Çerçevesinde Değerlendirilmesi. Dokuz Eylül Üniversitesi Iktisadi ve Idari Bilimler Fakültesi Dergisi, 31(1), 167-199.

Putnam, R. D., Leonardi, R., \& Nanetti, R. Y. (1993). Making Democracy Work, Civic Traditions in Modern Italy. Princeton University Press, New Jersey.

Putnam, R. D. (2000). Bowling alone: The collapse and revival of American community. Simon \& Schuster, New York.

Sabatini, F. (2006). The Empirics of Social Capital and Economic Development: A Critical Perspective. Nota di Lavoro-Working Paper, Fondazione Eni Enrico Mattei, No. 15, 1-35.

Tatlı, H. (2013). Yoksulluk ve Sosyal Sermaye: TRB1 Bölgesi'nde (Malatya, Elazığ, Bingöl, Tunceli) Bir Araştırma. (Doktora Tezi). Atatürk Üniversitesi Sosyal Bilimler Enstitüsü, Erzurum.

Tekin, A. N. (2015). Üniversite Öğrencilerinde İsssizlik Kaygısı: Süleyman Demirel Üniversitesi Öğrencileri Üzerinde Bir Araştırma. (Yüksek Lisans Tezi). Süleyman Demirel Üniversitesi Sosyal Bilimler Enstitüsü, Isparta.

Tektaş, N. (2014). Üniversite Mezunlarının Kaygı Düzeylerinin İncelenmesi. Selçuk Üniversitesi Sosyal Bilimler Enstitüsü Dergisi, Dr. Mehmet YILDIZ Özel Sayısı 2014, 243-253.

Türkiye İstatistik Kurumu (TÜIK). (2015). İstatistiklerle Gençlik/Youth Statistic 2014. Ankara: Türkiye İstatistik Kurumu Matbaası.

Türk Dil Kurumu (TDK) Online Sözlükleri, http://sozluk.gov.tr/.

Tüysüz, N. (2011). Sosyal Sermayenin Ekonomik Gelişme Açısından Önemi ve Sosyal Sermaye Endeksinin Hesaplanması. (Uzmanlık Tezi). Kalkınma Bakanlığı, Bölgesel Gelişme ve Yapısal Uyum Genel Müdürlüğü.

United Nations Educational, Scientific and Cultural Organization (UNESCO). 2015. Empowering Youth to Build Peace. Erişim Adresi: https://unesdoc.unesco.org/ark:/48223/pf0000234140.

Woolcock, M., \& Narayan, D. (1999). Social Capital: Implications for Development Theory, Research, and Policy. World Bank Research Observer, 15(2), 225-249.

Yeniçeri, N., Mevsim, V., Özçakar, N., Özan, S., Güldal, D. ve Başak, O. (2007). Tıp Eğitimi Son Sınıf Öğrencilerinin Gelecek Meslek Yaşamları İle İlgili Yaşadıkları Anksiyete İle Sürekli Anksiyetelerinin Karşılaştırılması. Dokuz Eylül Üniversitesi Tıp Fakültesi Dergisi, 21(1), 19-24.

Yıldırım, K., Koyuncu, C., Yazıcı, A. ve Erdoğan, M. (2013). Mikro Iktisat (e-kitap). Anadolu Üniversitesi Yayını 2632. Erişim Adresi: http://www.nevoku.com/mikro-iktisat--e-kitap--mikro-iktisat/ viewdeck/ab74d65b-65be-474e-bb19-08d27f8b2c43. 
